\title{
The Erzya Language. Where is it spoken?
}

L'erzja. Où le parle-t-on?

Jack Rueter

\section{(2) OpenEdition}

\section{Journals}

Electronic version

URL: https://journals.openedition.org/efo/1829

DOI: 10.4000/efo.1829

ISSN: 2275-1947

\section{Publisher}

INALCO

\section{Printed version}

Date of publication: 1 December 2013

ISBN: 978-2-343-04446-0

ISSN: 0071-2051

\section{Electronic reference}

Jack Rueter, "The Erzya Language. Where is it spoken?", Études finno-ougriennes [Online], 45 | 2013,

Online since 05 February 2015, connection on 08 July 2021. URL: http://journals.openedition.org/efo/ 1829 ; DOI: https://doi.org/10.4000/efo.1829

This text was automatically generated on 8 July 2021 .

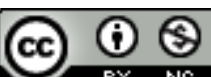

Études finno-ougriennes est mis à disposition selon les termes de la Licence Creative Commons Attribution - Pas d'Utilisation Commerciale 4.0 International. 


\title{
The Erzya Language. Where is it spoken?
}

L'erzja. Où le parle-t-on?

\author{
Jack Rueter
}

\section{Who speaks Erzya?}

1 The Erzya language is one of the two literary Mordvinic languages spoken in scattered settlements throughout the Volga Region and adjacent regions to the East. The Mordvinic literary languages Erzya and Moksha are members of the Finno-Volgaic subgroup of the Finno-Ugrian branch in the Uralic language family. Both languages have literary traditions dating back to the first half of the 19th century.

When considering the Erzya language in time and space, we should note that general historical information on this idiom is difficult to find, namely, Western tradition tends to apply the term "Mordvin" 1 in references made to all ethnic groups/subgroups regardless of the language they speak. The ethnonym "Arisa" "Erzya", it appears, is first mentioned at the end of the 10th century (see Cygankin 2000, p. 15).

The first written evidence of Erzya dates back to the first half of the 18th century, and the Nižnij Novgorod Gubernija in the word lists of Strahlenberg (1730), which despite the reference to the term "Mordvin" can be more specifically attributed to the Erzya language on the basis of lexica and phonology (see Feoktistov \& Saarinen 2005, pp. 13-14).

4 As a written language, Erzya dates back to the beginning of the 19th century. It first appeared in print in a catechism published in 1806. This publication was followed by the Gospel, printed in 1821/7339, and the remainder of the New Testament in $1827 .^{2}$ The first grammar, based on the Erzya-language text of the 1821 Gospel, was written by Conon von der Gabelentz and published 1838-39. ${ }^{3}$ Folk literature was first published in 1882-1883, and popular literature came to the fore in the late teens and early twenties of the 20th century. 


\section{Where are the dialects spoken}

5 Toward the end of the 19th century, a young Finnish scholar by the name of Heikki Paasonen set out for the homelands of the speakers of the Mordvin languages. In the land of the Erzya, Moksha, Shoksha, Teryukhan and Qaratay he documented language variants of numerous villages and settlements and amassed the materials for several volumes of folk poetry, (see Mordwinische Folksdichtung I-VIII). On the basis of Paasonen's collections a sizeable dialect dictionary was compiled (H.Paasonens Mordwinisches Wörterbuch), with dialect documentation from 96 Erzya-speaking and 60 Moksha-speaking settlements. ${ }^{4}$ The descriptions of the individual geographical lects are regularly formatted, and lexical information is given to the extent available in the collection, i.e. some settlements are represented by hundreds of entries, whereas others might show up only a few times. Needless to say, this six-volume dictionary, inclusive 2 indices, provides us access to Erzya and Moksha-speaking settlements. Geographically we are looking at an area from near Nižnij Novgorod (Erzya: Obran oš) $56^{\circ} 20^{\prime} \mathrm{N}$, in the north; to Novouzensk $50^{\circ} 27^{\prime} \mathrm{N}$, in the south; Spassk, Penza Oblast $43^{\circ} 11^{\prime} \mathrm{E}$, in the west, and Zlatoust $59^{\circ} 40^{\prime} \mathrm{E}$, in the east (cf. also Kuussaari 1935: Kartta VII, XII; Sarv 2002; Rueter 2010: p. 3).

6 Ermuškin (2004, p. 3-4) outlines a general area of Erzya-speaking settlements. They are found in the eastern raions of the Mordovian Republic, in the Sura River Basin, as well as the westernmost raions along the border with the Rjazan' and Nižnij Novgorod Oblasts, where the Shoksha live. ${ }^{5}$ Outside the Republic of Mordovia, settlements are found in the Republics of Tatarstan, Bashkortostan and Chuvashia, as well as the Oblasts of Orenburg, Penza, Nižnij Novgorod, Ul'janovsk, Samara and Saratov, with smaller concentrations in Central Asia, the Altai Republic and elsewhere.

7 Additional places of Erzya settlements or populations in the Russian Federation today might include: the Moscow Oblast, Kemerovski Oblast, Primorskij Krai, Rjazan' Oblast, Irkutsk Oblast, Sahalin Oblast, St Petersburg, Vladimir Oblast, Perm' Oblast, Tomsk Oblast, Čita Oblast. 
Populations mordves par région (2010)

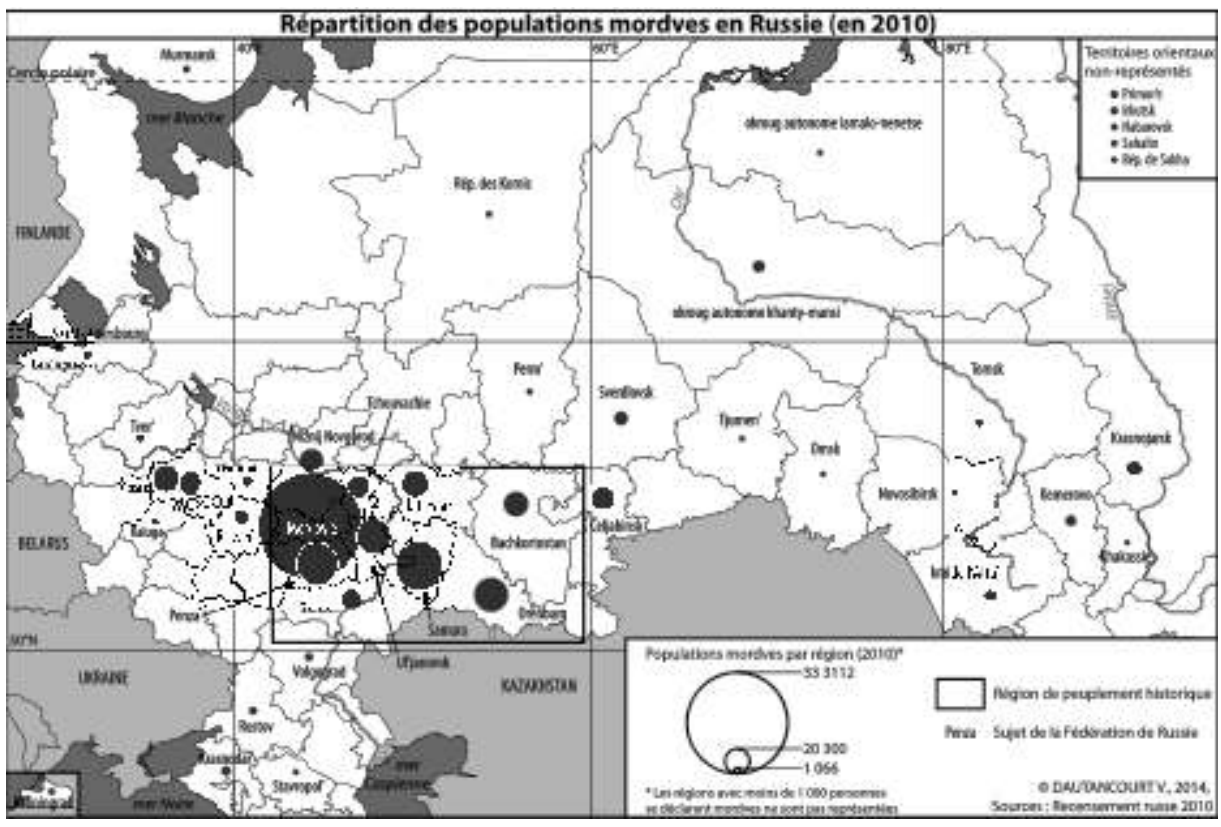

Source : Recensement russe 2010

Aire de peuplement des Erzas autour de la Volga

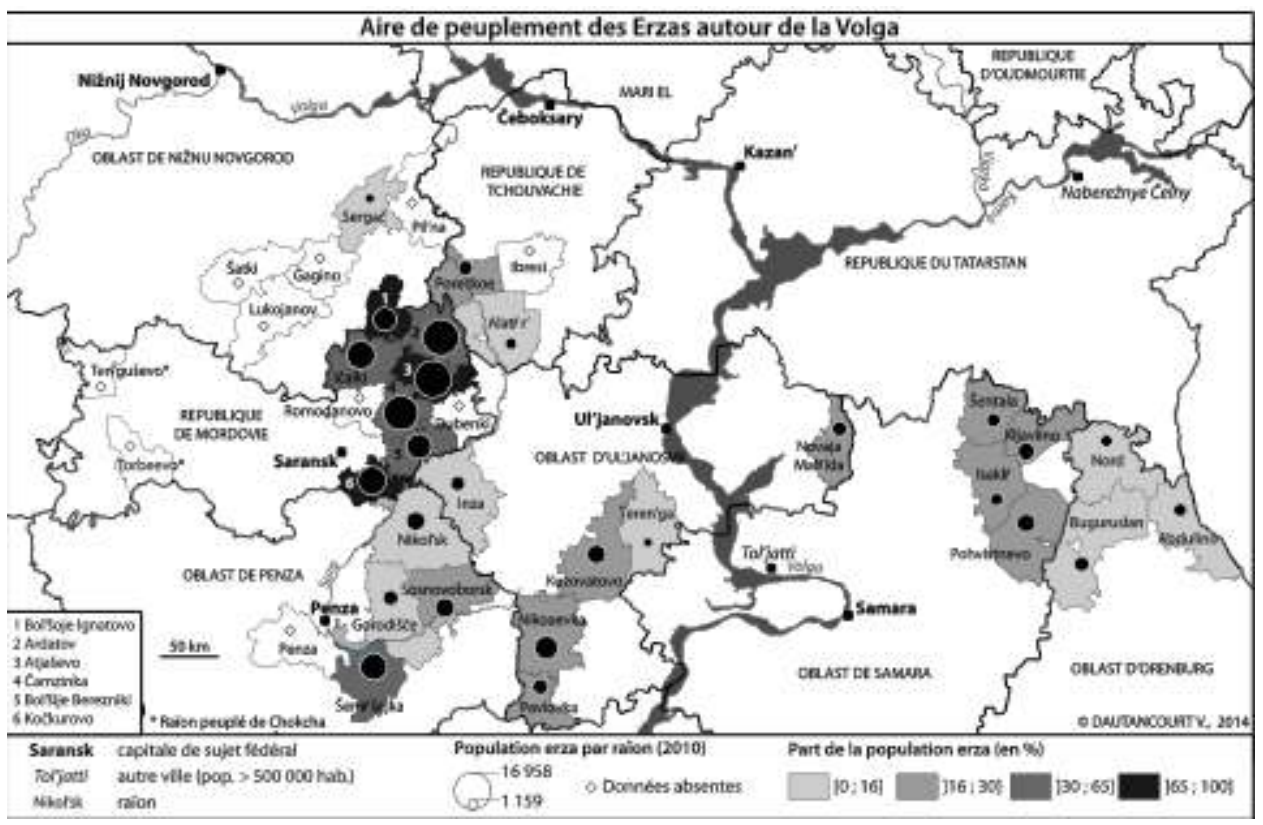

Copyright : V. Dautancourt

8 These areas are associated with the Erzya-speaking population by merits of their representing the conglomerate Mordvin ethnic unit represented in official demographic surveys conducted since 1926.

Ermuškin (ibid.) enumerates census statistics for the conglomerate Mordvin population, since it would appear that the last time linguistic distinctions were made was in the All-Soviet census of 1926. Of the 1.285 million who declared themselves to be of Mordvin background in 1959, 78\% declared themselves to be speakers of either Erzya 
of Moksha. In 19891.073 million declared a Mordvin background with 67.1\% speaking a Mordvin language as their native language. In the 2002 census the conglomerate Mordvin population was counted as 0.84 million, which is about 120 thousand more than the number of native speakers attested in the 1989 census -0.72 million. It might be noted that ethnic awareness was in style at the time of the 1989 census, whereas by the time of the 2002 census, centralization was getting the upper hand, thus reducing the desirability of specific minority affiliations. Only about $59.5 \%$ declared themselves to be native speakers of Erzya or Moksha. ${ }^{6}$ To put these percentages into perspective, however, we can say that according to the 1959 and 1970 census results less than $55 \%$ of the Soviet population was Russian, and less than $60 \%$ of the population declared Russian as their native tongue (cf. Taagepera 1971: p. 217).

According to Ermuškin, the 1926 census actually distinguished the Erzya and Moksha populations and determined that approximately two thirds of the population were Erzya and one third Moksha. He maintains that such a distribution might be representative of today's population, as well. Apparently, this concept of the distribution of Mordvins into Erzyans and Mokshans is generally shared by other Erzya and Moksha linguists (personal information).

\section{Tradition}

In Erzya literature various ideas are presented addressing the origins and distributions of the Erzya people.

In the epic Mastorava 'Mother Earth' compiled by Šaronov, Ineškipaz 'Great Creating God' sees that there is no one on Mother Earth, no one to fell the trees, no one to mow the meadows, no one to till the land or sow grain crops, and so the Great Creator decides to make humans. This entails the creation of Erzya, the Erzya language and Erzya traditions (cf. Šaronov 1994: p. 26-28).

13 The poem Tjuštja by Radaev ends with three young men setting off to seek their fortunes in the direction of the rising sun. They are to pass through three lands in three days on horseback on their journey and then they will come to a three-way fork, each is to choose his own way. The right fork does not bring quick fortune, you have to fight, of the many who traveled down it none have returned. The middle fork brings no regrets. And the left fork accumulates riches. (See Radaev 1991: p. 203-204).

14 In the novel Purgaz by Abramov (1988), the center of activities is Obran oš (the hill fort: 'Ashli,' 'ОшЕль'), near what is now known as Nižnij Novgorod. This central location in what was at one time part of the Volga Bulgar State, caught between the advancing populations of Eastern Slavs in the West and the Mongol-Tatar in the East has received little if any objective treatment as an individual entity.

15 Little profile has been given to the Erzya, who helped in the siege of Kazan'. If the Erzya are mentioned, they are generally mentioned as being on the side of Tsar Ivan IV (the Terrible). Judging from the dispersion of traditional Erzya settlements in the Volga region, however, it would appear that the Erzyas had fought, more than likely, both for and against the predecessors of present-day Russia. In fact, this population of the Volga region has been known for its uprisings in more recent times, and it has been associated with the names: Stenka Razin (1630-1671), Emel'jan Pugačëv (1742-1775), Kuz'ma Alekseev (1764-1810) and Vladimir Ul'janov (1870-1924). 
The volatility of the Erzya population originally in the Volga region can be seen in movement eastward and southward in times preceding the Soviet Era. As the tsars gained more control over traditional Erzya lands, and appropriated them to various lords, more and more of the Erzyans crossed the Volga in search of untaxed lands. This explains settlements as far south as Saratov west of the Volga, and large scattered settlements between Ul'janovsk and Samara, east of the Volga. From Samara settlements stretch eastward through Buguruslan and on toward Ufa. Settlements are found in Tatarstan, Bashkortostan and Kazakhstan, as well. One late exception to this rule can be observed in the Molokans who moved to what is now known as Shorzha, Armenia in the early 1840 s. $^{7}$

\section{Where will I hear Erzya spoken?}

17 Although Erzya is spoken on an everyday basis in the small Erzya villages of the Volga Region and beyond, a large percentage of the population has moved to larger settlements and centers.

\section{The setting}

The rural to urban cline can be broken down into three groups: the village, the posyolok (settlement) and the city. The village is where the majority of the residents are familiar with each other and have local family lineage extending over generations. The settlement, or posyolok, is readily confused with the village by outsiders, due to a policy of shared names. ${ }^{8}$ Beyond this, however, there may be a larger percentage of non-local residents, less long-term familiarity percentage-wise, and a higher percentage of nonErzya speaker population. The city has a marginal percentage of familiar faces, even though actual numbers of familiar Erzya speakers may soar.

\section{The village}

In the countryside, mainly villages, the Erzya language has its firmest rooting. It is here that one might find monolingual Erzya speakers: elderly women who have never had reason to leave their home village and preschool-aged children who have not yet become fluent bilinguals. At the shop and in unofficial gatherings the Erzya language is associated with familiar faces and those exhibiting obvious indications of Erzya speaker status, i.e. elderly people in village apparel will generally be addressed in Erzya. Unfamiliar young people and children in urban attire are generally addressed as nonErzyans, that is, in Russian. Door-to-door salesmen are usually local, and that means the person selling you insurance will also speak Erzya. If you need your plot plowed, you might talk to one of the tractor drivers or a dispatcher, in Erzya. Basically all conceivable daily needs might be taken care of in Erzya in villages with working-age Erzya-speaking populations.

20 At the interface between village life and the world beyond the tendency away from Erzya is readily observed. Official gatherings involving guests from the raion center, such as the opening ceremony for elementary schools, tend not to be conducted in the Erzya language. Primary schools also fall into this category. 
21 Although Erzya might be taught in the first four grades of school, there is often a question of whether Erzya is the medium of instruction or merely an elective subject taught outside of the regular school curricula. Optimally, children in the first four years of school receive instruction in the Erzya medium when Erzya-speaking teachers and study books are available (native language for grades 1-12, math 1-2, "the world around us" 1-4). ${ }^{9}$ This optimal situation, however, is uncommon: many of the teachers come from outside the villages and do not necessarily have a command of the Erzya language, and the availability of Erzya-language readers for different subjects cannot be commended, see institutions of education, below.

\section{The urban settlement (posyolok)}

While the number of Erzya-speaking inhabitants in a given posyolok may constitute high percentages, there is no guarantee of Erzya being spoken in larger gatherings. The population is heterogeneous consisting of Erzya speakers from different dialect backgrounds and people who do speak the Erzya language. Thus the default language of communication in, for example, Kemlja, Mordovia (pop. 4,872) is not Erzya. Children might learn to speak Erzya due to family-associated networking where both parents are Erzya speakers, as long as they are not sent off to schools elsewhere (personal information 1997-2004). When they come from mixed ethnic backgrounds, however, aptitude in Erzya for posyolok children tends to be passive or lacking altogether.

\section{The city}

In the novel/unfamiliar urban environment an issue arises involving percentage versus actual numbers, i.e. while Erzya speakers in a village setting may easily exceed 80 percent of the population and their numbers are in the hundreds, in the capital of Mordovia, Saransk, the percent of Erzya speakers is well below 10\% but their numbers are in the thousands. ${ }^{10}$ Although the number of actual speakers is much higher in the capital, the likelihood of running into an Erzya speaker is greatly diminished.

In moving to the city, Erzya-speaker $\mathrm{X}$ subjects himself/herself to every day routines where $90 \%$ of the random people met do not speak Erzya. In fact, of those possible $10 \%$ who might speak Erzya, there will be a sizeable portion who do not speak a variant familiar to X; X may simply choose to speak another language to insure mutual comprehension..$^{11}$ Outside of the home village, Erzya $X$ has initially become a member of a minority group ('from village $X$ ') within a minority group (Erzya speakers).

In order to retain one's minority identity, specific conscious decisions have to be made by that speaker. In an environment of majority-language assimilation (no enclave, ghetto or village), the choice of minority-language retention, maintenance and transfer to children is not one to be made by the lazy and lethargic. In order to maintain language transfer to a next generation, children might optimally be exposed to networks and multiple speakers interacting in the language. Such networks might include relatives, friends, institutions and media. For those who make no specific effort to retain a minority language over the generation gap, all that has to be done is let the children drift with the current. Then language retention will depend more upon peer pressure and institutions, which, in the urban centers of the Russian Federation, tend to pull the child away from minority-language orientation. 
Among cities traditions of minority intolerance can be detected even today. Only thirty odd years ago, it was the tendency for Erzya villagers along the rail line between Saransk and Kazan' to take their wares to the larger center, Kazan'. Although this tendency is open to speculation, there was a time when villagers were looked down upon in Saransk, in their village attire and with large sacks over their shoulders. Thus the Erzya language is also shunned by some in Saransk, even by those who insist on speaking Russian -with their own broken Russian accents (personal information, 1997-2004).

\section{Mordovia}

27 For those Erzya speakers coming from villages outside the Republic of Mordovia, especially those from east of the River Volga, the language of communication has always presented problems. It seems that within the Republic, which is closer to the center of the Federation, more pressure is put on the people to speak Russian. As the late Viktor Danilov put it "When he first came to Saransk, it was possible to travel from Tatarstan by bus to the Mordovian Republic, and the first time he had to use Russian to communicate was at the Mordovian border" (Danilov, p.c.). Perhaps, this is a question of location and multilingualism; Mordovia, being closer to the center of the Federation, has a lower toleration for multilingualism, whereas further east official bilingualism allows for or even promotes the acceptability of minority-language usage in institutions and settings outside the home. The lower toleration of minority languages in Mordovia might readily be associated with the exodus which began with the fall of Kazan' in 1552; those who wished to retain their way of life crossed the Volga.

\section{Institutions}

28 As mentioned above institutions might have an input on language retention. Some institutions, regardless of where the speaker of Erzya may live, have a greater effect than others. The most important institutions might include the family, and education these institutions are part of everyday life. Less frequent institutions might include church, theater, concerts and clubs.

\section{The family}

Within the general family with two parents, it will be noted that the setting tends to determine language learning by non-Erzya speaking adults. In a village where Erzya is spoken in the school, at the shop and at unofficial gatherings, one can still encounter non-Erzya speakers (40-50 years of age), who have learned Erzya as adults (personal information from Kabaevo, Mordovia and Korovino, Buguruslan 1997-2004). Here it is everyday life that dictates the practicality of a working knowledge in the local majority language. When both parents speak a language or have a comprehension of that language it is more likely that the children are also exposed to it. Of course, that also includes listening to radio and watching television, which is, most likely, not in Erzya. For the grandparents and relatives in the countryside with summer guests, the tendency seems to be that the children are addressed in the language they speak in the urban centers and city -Russian. Despite this, otherwise monolingual Russian-speaking children are often passively exposed to the everyday Erzya spoken by relatives, and 
therefore these children acquire a passive feel for the phonetics of the language. Hence when these children take classes in Erzya at the Mordovia State University, in Saransk, they, unlike new-comers to the Mordovia Republic, pick up Erzya with little accent at all (Ol'ga Erina, p.c.).

\section{Institutions of education}

The probability of receiving an Erzya-language education from preschool up through university depends on the definition and desirability, i.e. is Erzya a medium, a subject or both. If the Erzya language is taken to be the medium of all studies, there are no percentage points to be counted, the answer is simply zero. If the question is raised as to whether there have been Erzya-language instruction materials for the majority of subjects taught published over the past hundred years, we will find an interesting assortment. If, however, the question were posed as to whether the Erzya language could be learned at all three levels, primary, secondary and university, today the answer would actually give us hope for a notable probability.

In a village such as Batuševo (Erzya: Botužvele), which is over five kilometers from the nearest raion center, instruction is given in the Erzya language throughout the 8-year curriculum. In addition, teachers of subjects other than Erzya also use the Erzya medium to explain things relevant to the subject, provided, naturally, that the teacher speaks the language. It is difficult to establish, where Batuševo lies in the statistics of primary schools and Erzya-language instruction; official statistics are not cited, which might indicate the presence of a dilemma regarding obligations to rectify discrepancies in unequal education opportunities.

Although village schoolteachers are generally people who live locally, which might entail that they are themselves a member of community by birth or that they have married into it, it cannot be assumed that all schoolteachers speak a local variant of the Erzya language. In addition to teachers originally from the home village, there are also those from neighboring villages and even further away. Linguistically, this might mean that the teacher speaks a different dialect or does not speak Erzya at all (personal information, 1997-2011). If the teacher comes from a different dialect background, they might choose to be a stringent advocate of an unfamiliar normative language; whereas no regular radio or television broadcasts are attested. If the teacher is not proficient in the language of the pupils, the pupils might miss the gist of what is being taught simply because they do not understand their language-deficient teacher, who is probably a monolingual Russian speaker.

\section{Erzya-language study materials from the past century}

The variety and quality of study materials written in Erzya or translated requires a study of its own. An in-depth presentation of literature published in Erzya and Moksha between 1917 and 1977 was published in 1997 (Mordovia Bibliographical Index). Fields touched include: Social sciences, Philosophy, Sociology, Atheism, History, Economy, Demographic statistics, and that is just the first 6 categories of the index. This list is, of course, quite limited, and, more than likely, it does not meet the requirements of modern curricula for schools of any level.

What is being done to revive the use of Erzya in the schools? The children's journal Čilisema 'Sunrise' has attempted to alleviate the dearth of study materials in the Erzya 
language by publishing introductory articles on noteworthy people and fields of study. The Ministry of Education has ordered the publication of various schoolbooks: 'Mother Tongue,' 'The World around Us,' 'Mathematics'.12 Two encyclopedias have been published in the new millennium, which, despite the grammatically ill-formed titles моРДВАСь (that thar Mordvin), and мордовияСь энциклопЕдия (Mordovia is an encyclopedia), have well-translated articles and amount to approximately two thousand pages of encyclopedic documentation.

\section{Comments}

When applying for entry into a preschool in Saransk, there are certain requirements to be met. In addition to a physical check-up, an interview must be arranged with a local speech-language pathologist, who then writes a recommendation for acceptance to the preschool. With regard to my own two children, who have been spoken to in Erzya by their mother and in English by myself since birth -both languages were minority languages in Saransk- the speech-language pathologist warned that the children would definitely suffer from stuttering because we were not speaking to them in Russian. And as the pathologist did not realize I was a native speaker of English -my wife visited herthe pathologist insisted that at least one of us would have to speak to the children in Russian. My wife told the pathologist that we had planned on moving abroad in the not too distant future and that we had considered English to be a possible means of communication for the children elsewhere in the World.

After gaining admittance to a preschool, however, we noted that the workers were quite sympathetic and accommodating to our needs. Although they had no Erzyaspeaking teachers on staff, they did have one of the chefs come in on occasion to speak with the boys in Erzya. So the boys survived the time spent in Russian-language daycare with positive associations, and after the family moved to Finland in December of 2004 the boys continued to play in Russian, while their parents spoke only Erzya and English to them, until the end of March, 2005. It was surprising to see that within the first week that my elder son started attending English daycare all the children's games switched over to English. I wonder what would have happened had there been an Erzya-language daycare to attend in Saransk. ${ }^{13}$

\section{The Market}

Outside of village we find ourselves more dependent upon stores and the market place for our everyday needs. Where the village store also serves as a place for exchanging gossip and discussion of the news, which usually happens in Erzya, the posyolok and city settings are more problematic. In the latter two settings, Russian tends to be the default language for addressing unfamiliar people, even if the clerk does speak Erzya. So the question must be formulated as follows: Can you get service if you start in speaking Erzya?

Shop clerks are employed by the local store, and therefore they too tend to be local. Thus in a city, such as Saransk, where only every tenth person might be Erzya, the proportion of Erzya-speaking shop clerks is also low. Personal experience indicates that the open market tends to have more people selling their wares; they are people who have come from surrounding villages, and therefore it is much more likely that you will encounter an Erzya speaker there. 


\section{The Church} found encouraging for those who envision the church as a center for language usage and development. ${ }^{14}$ In Saransk, the Erzya-language translation of the New Testament has been lauded. The translation has received official approval from the Metropolitan Bishop of the Russian-Orthodox Church there, and the translation has readily gained a place in the local Lutheran Church, which was established there in the 1990s by members of the Erzya and Moksha intelligentsia. For the Russian-Orthodox masses, however, the language of the Church is Russian or Church Slavic, and the number of priests in Saransk who can speak Erzya can be counted on the fingers of one hand. In the Mordovian countryside, it will be observed, there are also Chuvash-speaking priests, so there is still hope that there might be an Erzya-speaking priest somewhere out there.

\section{Theater}

The national theater in Mordovia has received critical commentaries from many. One such critique is Marija Mal'kina, a Moksha writer, who questioned many features of this institution. Her contentions included at least three facts that should be found alarming. The Moksha and Erzya national theater, at least before 2005, tended to produce more foreign plays than ones by national playwrights. The directors were generally people without a knowledge of life in the Erzya or Moksha villages, their positions as directors were sidelines, i.e. they had full-time jobs elsewhere. Finally, there were instances of Moksha-language plays being translated into Russian and presented in Russian in Moksha villages (See Mal'kina 2005, p. 225-231).

41 In 2007 a new National Theater of Mordovia was opened in Saransk, and perhaps the critical commentaries are being taken into consideration. It is difficult to maintain a national theater when the budget depends on ticket sales -who can you afford to employ (cf. http://ru.wikipedia.org/wiki/ МОРДОВСКИЙ_ГОСУДАРСТВЕННЫЙ_НАЦИОНАЛЬНЫЙ_ДРАМАТИЧЕСКИЙ_ТЕАТР, http:// www.gidrm.ru/teatr_dram/)

\section{Communication}

42 Federation leaders, such as the president and the patriarch have visited the Republic of Mordovia at various occasions during the past decade. In preparation for each visit new projects have been undertaken to improve the infrastructure of the Republic. Roads are being paved and widened throughout, and cell phone networks are growing. The two computers that were donated to each and every village school by Putin and his legal wife are actually becoming available to users -although many of them are still under lock and key in the school director's office.

Cell phones are used in interpersonal communications regardless of the setting, and this means that more and more, Erzya can be heard on the streets and in public transportation. These one-sided bits of dialogue appear to bring the language out of hiding. And a passive presence in the larger settlements helps to encourage the use of Erzya as a medium of communication even when both parties are physically present.

Études finno-ougriennes, 45 | 2013 
ternet brings with it phenomena which further elicit use of the Erzya language. In addition to online journals and official sites of the Republic, which might have Erzyalanguages elements, Wikipedia has gone Erzya, and even the interfaces for VKontakte, Openoffice and Skype are being translated in to Erzya. Wikimapia has made it possible to locate settlements throughout the World, and although the authenticity of openaccess information may be questioned, Wikimapia appears to provide rudimentary demographic data that might be used for future research and fieldwork planning.

\section{In conclusion}

The Erzya language is traditionally spoken in scattered settlements located in the Volga Region, and adjacent Regions to the east. Developments over the past two centuries have also borne witness to resettlement in Armenia, Siberia, Central Asia and the Primorskij Krai.

Use of the Erzya language as a medium of communication can be approached with various scales and from different reference points. There is the rural-urban cline with the probability of encountering a fellow speaker of the language; the relation of proximity to the center of the Federation and multilingual tolerance. There are then the everyday institutions and networks, which can be viewed critically, but with little specifics on the actual state of Erzya language many issues are left unanswered.

The traditional stronghold of Erzya language and culture -the Erzya village- is threatened as more and more of the rural population moves to the city. This is a problem, however, which is faced worldwide now that over fifty percent of the world population is living in urban areas. Will we come to our senses and allow this peripheral remnant of harmony between humanity and the natural environment to enlighten us as we try to regain our balance with nature? The Erzya will retain at least elements of their language and culture as long as they are allowed to retain their dignity, even as peripheral, city-Ugrians ${ }^{15}$-can we retain ours?

\section{BIBLIOGRAPHY}

ABRAMOV 1988 = АБРАМОВ КУЗЬМА, 1988, ПУРГАЗ. САРАНСК: МОРДОВСКОЙ КНИЖНОЙ ИЗДАТЕЛЬСТВАСЬ.

CYGANKIN 2000 = ЦЫГАНКИН Д. В., МОРДОВСКИЕ ЯЗЫКИ ГЛАЗАМИ УЧЕНОГО-ЛИНГВИСТА, САРАНСК, ТИПОГРАФИЯ «КРАСНЫЙ ОКТЯБРЬ».

ERMUŠKIN 2004 = ЕРмУшкин ГРИГОРИЙ И., 2004, IX. Srednetëšskij dialekt èrzja-mordovskogo jazyka. (Als Manuskript vervielfältigt.) Mitteilungen der Societas Uralo-Altaica. Heft 24. Moskva Groningen: Faculteit der Letteren, Finoegristiek, Rijksuniversiteit Groningen.

ERZYA LANGUAGE, MORPHOLOGY 2000 = ЭРЗЯНЬ КЕЛЬ, МОРФОЛОГИЯ, 2000, ЭРЗЯНЬ КЕЛЬ, МОРФЕМИКА, ВАЛОНЬ ТЕЕВЕМА ДЫ МОРФОЛОГИЯ: ВУЗОНЬ ЭРЗЯНЬ ДЫ ФИННЭНЬ ОЖДЕЛЕНИЯНЬ 
ТОНАВТНИЦЯТНЕНЬ ТУРТОВ / РЕДКОЛЛЕГИЯСЬ: Д.В. ЦЫГАНКИН (ОТВ. РЕД., Н. А. АГАФОНОВА, М. Д. ИМАЙКИНА ДЫ ЛИЯТ. САРАНСК: ТИП. «КРАС. ОКТ.».

ETHNOLOGUE, online http://www.ethnologue.com/

FEOKTISTOV Aleksandr \& SAARINEN Sirkka, 2005, Mokšamordvan murteet, Suomalais-Ugrilaisen Seuran Toimituksia, 249, Helsinki, Suomalais-Ugrilainen Seura.

GABELENTZ Herr Conon von der, 1839, Versuch einer Mordwinischen Grammatik, Zeitschrift für die Kunde des Morgenlandes, II. 2-3, Göttingen: Druck und Verlag der Dieterlichschen Buchhandlung, S. 235-284, 383-419.

IMAJКINA 2008 = ИМАЙКИНА М. Д., 2008, НЕЕНЬ ШКАНЬ ЭРЗЯНЬ КЕЛЕСЬ. ФОНЕТИКА: УЧЕБНИК, САРАНСК: ИЗД-ВО МОРДОВ. УН-ТА.

КUDRJAŠOV 2007 = КУДРЯШОВ АБРАМ, 2007, РОДОСЛОВИЕ МОЛОКАН, ВЫСЕЛЕННЫХ ИЗ РОССИИ НА КАВКАЗ В 40-ЫХ ГОДАХ 19-ГО ВЕКА В ПОСЕЛОК НАДЕЖДИНО (ШОРЖА).

KUUSSAARI Eero, 1935, Suomen suvun tiet. Kuvaus Suomen sukukansojen kehityksestä sekä tuhatvuotisista vaelluksista ja valtataisteluista, Suomen heimosoturien liitto, Helsinki.

MAL'KINA 2005 = МАЛЬКИНА МАРИЯ, ЭРЯФТЬ ВАЙГЯЛЕНЗА, САРАНСК: МОРДОВСКЯЙ КНИЖНАЙ ИЗДАТЕЛЬСТВАСЬ.

MORDOVIA BIBLIOGRAPHICAL INDEX 1977 = МОРДОВИЯТЬ КНИГАЦ $=$ МОРДОВИЯНЬ КНИГАСЬ $=$ КНИГА М 79 МОРДОВИИ: БИБЛИОГР. УКАЗ. (1917-1977) / НАЦ. Б-КА ИМ. А. С. ПУШКИНА; СОСТ. Л. Е. КУЛИКОВА. САРАНСК.

MORDWINISCHE 1938 = Mordwinische Volksdichtung I. Band, Gesamm. von H. Paasonen, Hrsg. und übers. von Paavo Ravila, MSFOu LXXVII, Helsinki: Société finno-ougrienne.

MORDWINISCHE 1939 = Mordwinische Volksdichtung II. Band, Gesamm. von H. Paasonen, Hrsg. und übers. von Paavo Ravila, MSFOu LXXXI, Helsinki: Société finno-ougrienne.

MORDWINISCHE 1941 = Mordwinische Volksdichtung III. Band, Gesamm. von H. Paasonen, Hrsg. und übers. von Paavo Ravila, MSFOu LXXXIV, Helsinki: Société finno-ougrienne.

MORDWINISCHE 1947 = Mordwinische Volksdichtung IV. Band, Gesamm. von H. Paasonen, Hrsg. und übers. von Paavo Ravila, MSFOu XCI, Helsinki: Société finno-ougrienne.

MORDWINISCHE 1977a = Mordwinische Volksdichtung V. Band, Gesamm. von Ignatij Zorin, durchges. u. transkr. von Heikki Paasonen, übers. von Kaino Heikkilä \& Paavo Ravila, hrsg. von Martti Kahla, MSFOu 161, Helsinki: Société finno-ougrienne.

MORDWINISCHE 1977b = Mordwinische Volksdichtung VI. Band, Gesamm. von Ignatij Zorin, durchges. u. transkr. von Heikki Paasonen, übers. von Kaino Heikkilä \& Paavo Ravila, hrsg. von Martti Kahla, MSFOu 162, Helsinki: Société finno-ougrienne.

MORDWINISCHE 1980 = Mordwinische Volksdichtung VII. Band, Gesamm. von Makarij Evsev'ev, Ivan Shkol'nikov, Andrej Shuvalov u. Mihail Tarajkin, durchges. u. transkr. von Heikki Paasonen, übers. von Kaino Heikkilä, hrsg. von Martti Kahla, MSFOu 176, Helsinki: Société finno-ougrienne. MORDWINISCHE 1981 = Mordwinische Volksdichtung VIII. Band, Gesamm. von Roman Uchaev, Sergei Chigin \& Vladimir Savkin, durchges. von Heikki Paasonen, transkr. u. übers. von Kaino Heikkilä, hrsg. von Martti Kahla, MSFOu 178, Helsinki: Société finno-ougrienne.

NAGY József, 2004, “The Mordvins, A historical overview”, in The Finno-Ugric World, Budapest, György Nanovfszky (ed. in chief), p. 91-94. 
PAASONEN $1990=$ H. Paasonens Mordwinisches Wörterbuch, Band I (A-J), Zusammengestellt von Kaino Heikkilä, Unter Mitarbeit von Hans-Hermann Bartens, Aleksandr Feoktistow und Grigori Jermuschkin bearbeitet und herausgegeben von Martti Kahla, Lexica Societatis Fenno-Ugricae XXIII, 1. Kotimaisten kielten tutkimuskeskuksen julkaisuja 59, Helsinki: Suomalais-Ugrilainen Seura \& Kotimaisten kielten tutkimuskeskus.

PAASONEN $1992=$ H. Paasonens Mordwinisches Wörterbuch, Band II (K-M), Zusammengestellt von Kaino Heikkilä, Unter Mitarbeit von Hans-Hermann Bartens, Aleksandr Feoktistow und Grigori Jermuschkin bearbeitet und herausgegeben von Martti Kahla, Lexica Societatis Fenno-Ugricae XXIII, 2. Kotimaisten kielten tutkimuskeskuksen julkaisuja 59, Helsinki: Suomalais-Ugrilainen Seura \& Kotimaisten kielten tutkimuskeskus.

PAASONEN $1994=$ H. Paasonens Mordwinisches Wörterbuch, Band III (N-Ŕ), Zusammengestellt von Kaino Heikkilä, Unter Mitarbeit von Hans-Hermann Bartens, Aleksandr Feoktistow und Grigori Jermuschkin bearbeitet und herausgegeben von Martti Kahla, Lexica Societatis Fenno-Ugricae XXIII, 3. Kotimaisten kielten tutkimuskeskuksen julkaisuja 59, Helsinki: Suomalais-Ugrilainen Seura \& Kotimaisten kielten tutkimuskeskus.

PAASONEN 1996 = H. Paasonens Mordwinisches Wörterbuch, Band IV (S-Ž), Zusammengestellt von Kaino Heikkilä, Unter mitarbeit von Hans-Hermann Bartens, Aleksandr Feoktistow und Grigori Jermuschkin bearbeitet und herausgegeben von Martti Kahla, Lexica Societatis Fenno-Ugricae XXIII, 4. Kotimaisten kielten tutkimuskeskuksen julkaisuja 59, Helsinki: Suomalais-Ugrilainen Seura \& Kotimaisten kielten tutkimuskeskus.

RADAEV 1991 = РАДАЕВ ВАСИЛИЙ, ТЮШТЯ, САРАНСК: МОРДОВСКОЙ КНИЖНОЙ ИЗДАТЕЛЬСТВАСЬ. RUETER Jack, 2010, Adnominal Person in the Morphological System of Erzya. MSFOu 261, Helsinki: Société finno-ougrienne.

SALo Merja, 1991, «Mordvalaiset», in: Johanna Laakso (ed.), Uralilaiset kansat, Tietoa suomen sukukieliestä ja niiden puhujista, Porvoo - Helsinki - Juva, s. 156-184.

SARV Heno, 2002, Indigenous Europeans East of Moscow. Population and Migration Patterns of the Largest Finno-Ugrian Peoples in Russia from the 18th to the 19th Centuries, Dissertation Geographicae Universitatis Tartuensis, 17, Tartu.

ŠARONOV 1994 = ШАРОНОВ АЛЕКСАНДР, МАСТОРАВА, САРАНСК ОШ: МОРДОВИЯНЬ КНИГАНЬ ИЗДАТЕЛЬСТВАСЬ.

STRAHLENBERG Philip Johan Tabbert von, 1730, Nord-Und Ostliche Theil Von Europa Und Asia, in so weit solches Das ganze Russische Reich mit Sibirien und der grossen Tatarey in sich begreiffet: in einer historisch-geographischen Bescreibung der alten und neuern Zeiten, und vielen andern unbekannten, Stockholm: In Verlegung des Autoris.

TAAGEPERA Rein, 1971, “The 1970 Soviet Census: Fusion or Crystallization of Nationalities?”, Soviet Studies, pp. 216-221.

WIEDEMANN Ferdinand Johann, 1865, Grammatik der ersa-mordwinischen Sprache nebst einem kleinen mordwinisch-deutschen und deutsch-mordwinischen Wörterbuch, Mémoires de l'Académie impériale des sciences de St.-Pétersbourg, VII ${ }^{\text {e }}$ Série, Tome IX, № 5. 


\section{NOTES}

1. The term "Mordvin" can be traced back to Getica by Jordanes dating to ca. 551 A.D. "Mordvin" is an exonym and is used especially in the majority-language Russian as an umbrella term to identify the ethnic groups Erzya, Moksha, Qaratay and Teryukhan of today (cf. Nagy 2004, p. 91-94; Cygankin 2000, p. 15). The native speakers of Erzya and Moksha refer to themselves as Erzya and Moksha in their native languages, whereas "Mordvin" and its derivates are generally felt to be derogatory.

2. After the first printing of the Gospel in Erzya (1821) and the completion of the New Testament (1827), a second translation of the Gospel appeared in 1910, and a complete new translation of the New Testament into Erzya was published in 2006, (cf. Ethnologue: online).

3. Notably, subsequent grammars of Erzya have appeared in 1865 by F. J. Wiedemann, 1929 by M. E. Evsev'ev, 2000 by Cygankin et al. (eds) and 2008 by M. D. Imajkina.

4. See also http://www.ling.helsinki.fi/ rueter/HP/mwDialLocales.shtml

5. The Shoksha idiom has at times been associated with the Moksha language and presently is considered to be a dialect of the Erzya language. There are merits in both associations, but there is also the possibility that Shoksha actually represents its own branch of the Mordvinic protolanguage, (D. V. Cygankin, p.c.).

6. The question that arises here is what the census counters actually asked: did they ask whether the interviewee spoke Erzya or Moksha, or did they ask whether the interviewee spoke Mordvin? (Russian, Ukranian and Belorus speakers were not asked if they spoke "Slavic.")

7. cf. http://molokane.org/places/FSU/Mordovia/2004_TV_Babylon.html, http:// www.sandikov.name/book.htm, Ethnologue online.

8. In the Republic of Mordovia and surrounding areas it is common-place to have adjacent settlements bearing the same name. In Atjaševo Raion, one encounters the old village Atjaševo (OŤažvele), with a wooden church, concrete-plate and dirt roads, located about three kilometers from the posyolok Atjaševo, with rail connections and raion-center status. In Chuvashia we can find an analogy in the name Atră̌. The old villages are Erzya-speaking with minimal infrastructure, whereas the posyoloks are heterogeneously populated and boast a more comfortable life-style.

9. Instruction in the native language (subject and medium) is promoted by the presence of native-speaking teachers who are able to offer Erzya-language assistance to their pupils in the various subjects taught in primary schools. In addition to the study books available the teachers might utilize materials published in the children's journal Čiliśema 'Sunrise.' Thus subjects nolonger supported by school books (era beginning in approximately the 1970s) might still be addressed in the introductory phase in Erzya.

10. According to the 2010 figures, there are approximately 297,400 people living in Saransk, Mordovia. Of these, $21 \%$ have specified an ethnic affiliation that has been recorded as Mordvin in official statistics, so we might construe a maximal $10 \%$ of the population as Erzya speakers $(29,740)$ - there are purportedly more Mokshas than Erzyas in Mordovia. It should be noted that census interviewers for the 2002 All-Russian census have been "advised" unofficially to render, where possible, all references to Erzya, Moksha, Shoksha, Teryukhan, Qaratai, Murza and Mordvin as Mordvin or "Mordvin" (personal information). In Mordovia, the ethnic groups Moksha and Erzya were not among the official choices enumerated in the census.

11. Although there are radio and television broadcasts in the Erzya language in Saransk, which might nurture the concept of a mutually comprehensible normative language, there are three basic deterrents to be observed: a) length of air time can be measured in terms of tens of minutes per week in both media; b) broadcast schedules are only approximate (30 minutes either way or not at all, on day-of-broadcast knowledge), and c) broadcasting is not directed toward Erzyaspeaking villages and settlements. 
12. School books, it will be noted, might be published for a readership of 2000-3000, that is about 4-6 books per school in the Republic of Mordovia, where one third of the population lives.

13. Officially, there were supposed to be Erzya-language daycares in Saransk, but statistics and reality do not always correlate with practical daily routines, such as going to work at the university, where both parents teach.

14. The original translation of the New Testament dates back to the beginning of 19th century, as noted above, and no translation was suggested in 1868 by the Kazan' Translation Committee; the Mordvins were soon to abandon their language, all together (see Salo 1991: p. 164). The 1880s did see a re-emergence of Bible translation activity and the Gospel was translated a couple more times before the October Revolution (latest 1910).

15. Cf. Jouni Tossavainen: Only the Outsider. Paris, 2011

\section{ABSTRACTS}

This article deals with Erzya, their affiliations, where they live and where their language is spoken. A geographical presentation is outlined for where Erzya has been traditionally spoken over the past one hundred years, as documented in the collections of Heikki Paasonen. Use of the language as a medium of communication is assessed in the rural and urban settings of various institutions: the family, education, the market, the Church and theatre. Due to limited official documentation of the Erzya as a nation or ethnic group, some of the facts are based upon personal experience and information accumulated by the author during his many trips to the Volga Region between 1992 and 2007. The Erzya language is encountered in many of the countries of the former Soviet Union. It is used the most in the rural setting in non-official matters. The new media of today: telephones, Wikimedia, etc. provide Erzya with a new niche in urban communication.

Cet article porte sur les Erzas, sur leurs relations, leur lieu d'habitation et la langue qu'ils parlent. Il présente la zone géographique où la langue a été traditionnellement parlée dans les cent dernières années, comme le montrent les documents recueillis par Heikki Paasonen. Il évalue l'utilisation de la langue comme moyen de communication dans les zones rurales et urbaines ainsi que dans diverses institutions : la famille, l'école, le marché, l'église et le théâtre. En raison de la faible documentation officielle disponible sur les Erzyas en tant que nation ou que groupe ethnique, certains des faits reposent sur l'expérience personnelle de l'auteur et les informations qu'il a pu collecter durant ses nombreux séjours dans la région de la Volga entre 1992 et 2007. On trouve l'erzja dans de nombreux pays qui faisaient partie de l'Union Soviétique; la langue est parlée surtout à la campagne, dans un cadre non officiel. Mais les nouveaux media - téléphone, wikimedia etc. - offrent à l'erzja un nouveau créneau dans la communication en milieu urbain. 


\section{INDEX}

Mots-clés: Mordve, erza, usage linguistique

Geographical index: Kazakhstan, Altaï (République), Vladimir (oblast'), Penza, Nižni-Novgorod, Orenburg (oblast'), Sakhaline (oblast'), Korovino, Mordovie (République), Novy Uzensk, Spassk, Saransk, Atyaševo, Batuševo, Kemlja, Kabaevo, Bachkortostan (République), Tatarstan (République), Tchouvachie (République), Atrat', Tchita (oblast'), Tomsk (oblast'), Irkoutsk (oblast'), Zlatoust, Sura (rivière), Oulianovsk, Volga (vallée de la)

Keywords: Morvinian, Erzya, language use, Moksha, Mordvin, Shoksha, Altai, Finno-Ugric Republics, Mordovia, Novy Uzensk, Spassk, Saransk, Atyashevo, Batushevo Kemlya, Kabayevo, Zlatoust, Moscow Oblast, Nizhny Novgorod, Orenburg Oblast, Buguruslan, Korovino, Penza, Perm Oblast, Primorski Krai, Ryazan Oblast, Saint Petersburg, Samara, Saratov, Siberia, Chita Oblast, Irkutsk Oblast, Kemerovski Oblast, Sakhalin Oblast, Tomsk Oblast, Sura, Bashkortostan, Chuvashia, Atră̌, Tatarstan, Ulyanovsk, Vladimir Oblast, Volga

nomsmotscles Erzas, Mokchas, Mordves, Šokšas 